\title{
COMMUNITY BASED TOURISM (CBT) TO ESTABLISH BLUE ECONOMY AND IMPROVE PUBLIC WELFARE FOR FISHING TOURISM DEVELOPMENT IN KLATAK BEACH, TULUNGAGUNG, INDONESIA
}

\author{
SUMARMI" \\ Universitas Negeri Malang, Faculty of Social Science, Geography Department, Malang, Indonesia, e-mail: sumarmi.fis@um.ac.id \\ Elya KURNIAWATI \\ Universitas Negeri Malang, Faculty of Social Science, Sociology Department, Malang, Indonesia, e-mail: elya.kurniawati.fis@um.ac.id
}

\author{
Muhammad ALIMAN
}

Universitas Negeri Malang, Faculty of Social Science, Geography Department, Malang, Indonesia, e-mail: muhammad.aliman.1607219@students.um.ac.id

\begin{abstract}
Citation: Sumarmi, Kurniawati, E., \& Aliman, M. (2020). COMMUNITY BASED TOURISM (CBT) TO ESTABLISH BLUE ECONOMY AND IMPROVE PUBLIC WELFARE FOR FISHING TOURISM DEVELOPMENT IN KLATAK BEACH, TULUNGAGUNG, INDONESIA. GeoJournal of Tourism and Geosites, 31(3), 979-986. https://doi.org/10.30892/gtg.31307-530
\end{abstract}

\begin{abstract}
Klatak Beach has long been known by Tulungagung community, but it became famous after the construction of the southern crossing lane (Jalan Lintas Selatan). There were not many visitors who come there either. Currently, Klatak Beach was developed as a tourism area. This research aimed to find out: the potential of Klatak Beach, Tulungagung Regency in the development of fishing tourism, the community empowerment in lobster fishing tourism, and the strategy for developing lobster fishing tourism in Klatak Beach to create Blue Economy. This research used descriptive methods with quantitative and qualitative analysis techniques. The data used in this study are primary and secondary data, such as focus group discussions (FGD) with related parties. Secondary data were collected from government agencies, institutions, and the community. Data collection on this research was the primary data collected through interview and observation and also secondary data. Hierarchy Analysis Process (AHP) are used to create policy alternatives of Blue Economy. The results showed that Klatak Beach was potentially to develop as the tourism area. The empowerment on the Klatak Beach community has been done great by three groups of fishermen, namely Mina Klatak, Rayap Pereng, and Pereng Mania. The policy made by the fishermen group and the government of Tulungagung Regency has supported to create a blue economy.
\end{abstract}

Key words: Fishing Tourism, Community Based Tourism, Public Welfare, Blue Economic

$* * * * * *$

\section{INTRODUCTION}

Indonesia is the largest archipelago country in the world, which has $\pm 18,110$ of large and small islands, with a coastline length of $108,000 \mathrm{~km}$. Based on The Sea Law (UNCLOS) in 1982, Indonesia has authority over the water area of $3.2 \mathrm{million} \mathrm{km}^{2}$ consisting of 2.9 million $\mathrm{km}^{2}$ of the islands and 0.3 million $\mathrm{km}^{2}$ of the territorial sea. Indonesia also has the exclusive right to use marine resources and various related things that covered over 2.7 million $\mathrm{km}^{2}$ in EEZ water zone (up to 200 miles from the baseline) (Bengen, 2010; Hakim, 2013).

The use of marine resources needs to look at sustainability factors. The amount of natural damage that exists on land and in waters will threaten the economic sustainability. Meanwhile, the development challenges were becoming increasingly complex as the result of high population growth, acceleration of global economic changes and also climate change. Therefore, it needs a sustainable development policy. The Blue Economy was chosen as one of the economic policies. Coastal areas have great economic potential to support the economy of communities, especially the fishing communities (Priyono, 2016). The concept of Blue Economy is needed to answer challenges of the existing development systems that tend to be exploitative and damage the environment and exceed the carrying capacity of the environment (Bari, 2016). It hoped that by implementing Blue Economy, the community's economy would increase, then the people will become more prosperous, but the sky and sea will remain blue (sustainable) (Rekdale, 2013; Satria, 2009).

Some tourism activites was usually only benefit for some group of enterpreneurs. As an example of research conducted in the Maldives showed that tourism activities are only dominated by upper-class entrepreneurs who are interested in providing guesthouses, tours and travel (Giampiccoli et al., 2020). Therefore, it is necessary for tourism management to make Community-Based tourism (CBT). The main objective of development was to improve the welfare of the community, and then the fishing communities around the coast are included.

Fishing tourism development in Indonesia has existed in several regions as in West Lombok, community groups that manage floating net cages (Keranda Jaring Apung) on Nanggu Island as underwater tourism sites and fishing tours. The results of fishing tourism development in these locations have experienced a significant increase in economic income. This area not only relies on tourist visits and boat rentals but also benefits from the farming of grouper fish, pomfret fish and lobster ordered by many restaurants and hotels around West Lombok (Budiawati, 2013). In Nurwenda's research (2013), the highest income was obtained from fishing tourism in comparison of fishermen household income and the results of fisheries activity and tourism in Santolo Beach, Garut Regency, West Java. The other business types of fishing tourism in this location still have potential that can be developed in order to increase regional income by promoting and increasing facilities and infrastructure on Santolo Beach. Fishing tourism of floating net cages (KJA) has also been developed at Lake Maninjau, West Sumatra. This tourism proved that had contributed socially and economically to the communities around the lake (Firdaus et al, 2019). However, research related to KJA tourism on the southern coast of Java has not been much studied. Therefore, this research focuses on the management of fisheries tourism community-based (CBT) of floating net cages (KJA) in Klatak Beach, Tulungagung Regency, Indonesia.

\section{LITERATURE REVIEW \& THEORITICAL FRAMEWORK}

Besides looking to improve the economy, coastal tourism management also needs to check the sustainability of beach conservation. According to (Inskeep and WTO, 1998), several approaches are considered in tourism planning, included: (1) Continuous Incremental, and

\footnotetext{
Corresponding author
} 
Flexible Approach, (2) System Approach, (3) Comprehensive Approach, (4) Integrated Approach, (5) The environmental and sustainable development approach, (6) Community Approach, is an approach that is supported and raised by (Mitchell and Murphy, 1991) which emphasizes the importance of maximizing the involvement of local communities in tourism planning and decision-making processes, to increase the desires and possibilities, it is necessary to maximize public participation in the development and management in tourism as well as its social-economic benefits, (7) Implementable Approach, and (8) Application of systematic planning approach.

Three main principles in sustainability development (McIntyre, 1993; Dahuri, 2001, Fandeli, 1997) as follows: (1) Ecological Sustainability, ensures that the development aligns with the ecological, biological, and diversity of existing ecological res ources. (2) Social and Cultural Sustainability, which ensures that the development has a positive impact on surrounding communities and align with the culture and values that apply to the community. (3) Economic Sustainability, which ensures that the development is economically efficient and that the resources used can last for future needs.

Tourism development that has Economic Sustainability used Community-Based Tourism (CBT). Community-Based Tourism is a type of tourism development that aims to counteract the negative impacts of conventional/mass tourism. It is growing in popularity and specifically intended for disadvantaged members in society. Most of the benefits should go to the people who make tourism happen in their localities the small local operators. This is a necessary imperative to grow local economies and provide employment and incomes for local people through their own entrepreneurship (Mearns and Lukhele, 2015; Arintoko et al., 2020; Kazimoto, 2013).

Sustainable CBT aims to reconcile the tensions between the three partners in the development triangle and maintains the equilibrium in the long-term. It highlights the aims of sustainable CBT, namely: to minimize the environmental and cultural damage, optimize visitor satisfaction and maximize long-term economic growth for the region. Sustainable tourism (ST) is tourism that does not deplete economic, social/cultural and environmental resources. Over the past decades, sustainability has become a focal point for tourism devel opment around the world. Matarrita-Cascantea et al. (2010:9) state that ST is not just about controlling and managing the negative impacts of the industry. ST development aims to benefit local communities, economically and socially, and to raise awareness and support for conservation of the environment (Kurniawati et al., 2020).

The idea of Blue Economy was raised by Prof. Gunter Pauli in 1994 when the Belgian professor was asked by the United Nations (UN) to explain the future business model (Rekdale, 2013; Saaty, 1993). Blue Economy with a variety of theories and formulas offered by economists in the world, then it began to widely discuss in Indonesia because Indonesia is rich in marine resources. Blue Economy is a concept that explains economic activities that not only reduce waste but also improve the community's economy (McKinley, 2019). It also interpreted as the Blue Sea Economy, which makes the sea as an ecosystem that must be protected and optimized for its benefits in order to improve the people's economy. Blue Economy Indonesia aims to achieve comprehensive national development by empowering elements related to Blue Economy and maintaining the sustainability of the sea (Apriliani, 2014).

Indonesia's aquatic potential is very rich compared to other Asian countries. Evidence showed that Indonesia has potential aquatic wealth which can be seen in the comparative graph of the potential trade of fish between countries in ASEAN (Indonesia, Vietnam, Thailand, Malaysia, Myanmar, Singapore, the Philippines, Brunei Darussalam, Cambodia, and Laos) between 2015-2019 as follows:

Table 1. Values of Fish Export Commodities Intra-ASEAN (in thousands of US dollars) Sumber: International Trade Center, 2020

\begin{tabular}{|c|c|c|c|c|c|c|c|c|c|}
\hline \multirow{2}{*}{ Exporters } & \multicolumn{9}{|c|}{ Exported Value } \\
\hline & 2015 & & 2016 & & 2017 & & 2018 & & 2019 \\
\hline Viet Nam & $\$ 4,838,124$ & $\$$ & $5,184,388$ & $\$$ & $6,141,701$ & $\$$ & $6,407,588$ & $\$$ & $5,609,383$ \\
\hline Indonesia & $\$ 2,649,783$ & $\$$ & $2,900,604$ & $\$$ & $3,271,472$ & $\$$ & $3,311,916$ & $\$$ & $3,274,855$ \\
\hline Thailand & $\$ 1,744,039$ & $\$$ & $2,022,322$ & $\$$ & $2,123,301$ & $\$$ & $1,962,071$ & $\$$ & $1,839,700$ \\
\hline Malaysia & $\$ 505,436$ & $\$$ & 517,473 & $\$$ & 509,590 & $\$$ & 537,379 & $\$$ & 649,179 \\
\hline Myanmar & $\$ \quad 446,543$ & $\$$ & 537,915 & $\$$ & 662,237 & $\$$ & 734,172 & $\$$ & 473,589 \\
\hline Philippines & $\$ \quad 473,265$ & $\$$ & 448,517 & $\$$ & 468,865 & $\$$ & 421,613 & $\$$ & 372,085 \\
\hline Singapore & $\$ \quad 265,159$ & $\$$ & 264,747 & $\$$ & 265,001 & $\$$ & 282,368 & $\$$ & 236,081 \\
\hline Cambodia & 465 & $\$$ & 672 & $\$$ & 596 & $\$$ & 795 & $\$$ & 23,179 \\
\hline Brunei & 3,114 & $\$$ & 5,054 & $\$$ & 5,447 & $\$$ & 7,850 & $\$$ & 3,462 \\
\hline Laos & 132 & $\$$ & 72 & $\$$ & 31 & $\$$ & 20 & $\$$ & 4 \\
\hline
\end{tabular}

The following graph showed the export numbers of the fish commodities in ASEAN country from 2015 to 2019.

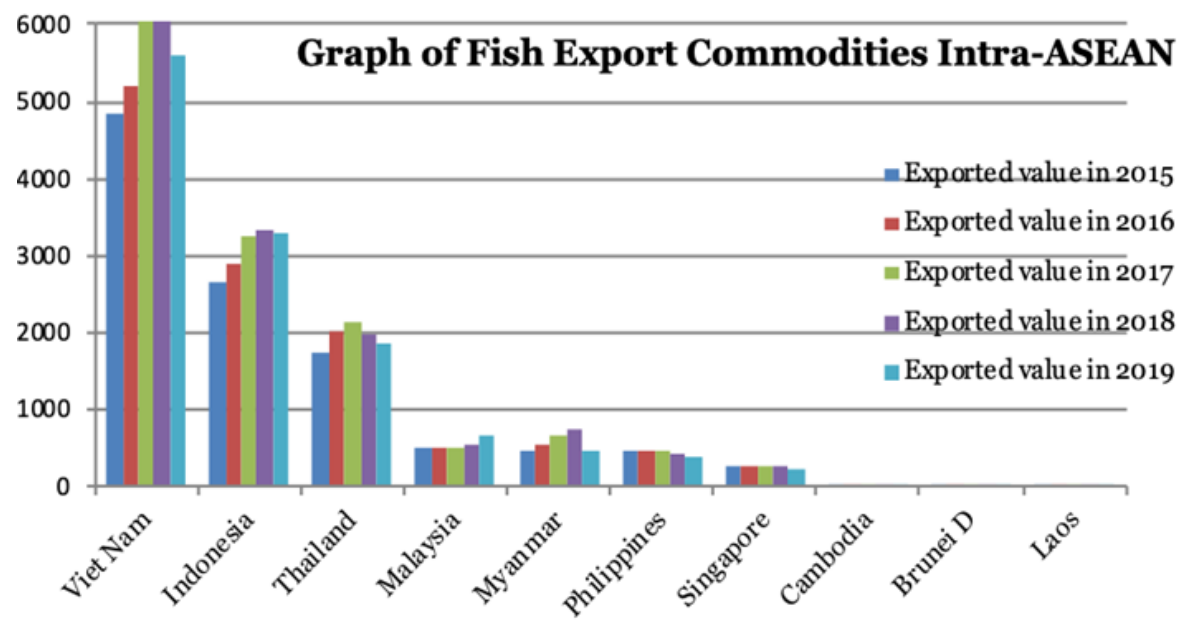

Figure 1. Fish Export Commodities Intra-ASEAN (in thousands of US dollars) (Sumber: International Trade Center, 2020)

According to Law No. 31 of 2004 on Fisheries, fisheries are all activities related to the management and utilization of fish resources and the environment starting from preproduction, production, management and marketing in the fishing business. Meanwhile, according to Law 
No. 10 of 2009 on tourism and Undang-Undang No 1 Tahun 2014 on Management of Coastal Areas and Small Islands, tourism is a variety of tour activities supported by various facilities and services provided by the community, entrepreneurs and government. Fisheries and tourism activities can be integrated into the form of tourism. According to Dermawan and Aziz (2012); Hakim (2013), tourism in terminology defined as an integrated conservation-based management approach with a focus on the development of fisheries and marine tourism. Conceptually, fishing tourism development refers to the principle of ecotourism development, such as (1) preventing and overcoming the impact of tourist activities on nature and culture that adapted to nature and local culture, (2) environmental conservation education that educates visitors and surrounding communities about the importance of conservation, (3) direct income for the area in the for $m$ of retribution or conservation tax can be used for conservation management, (4) community participation in planning session, (5) income for the community, (6) harmony of nature, (7) carrying capacity for utilization with power capacity by considering the carrying capacity of the environment, and (8) revenue contribution to the State. According to Haris (2012); Hakim (2013) fishing tourism can distinguish into two patterns of the use of space and resource, which is fishing tourism as a part of the use of fishing and tourism area and resources integration, and fishing tourism as a combination of the use of fishing and tourism area and resources integration.

\section{METHODOLOGY}

\section{Population and Participant}

Tulungagung Regency has many beaches, such as Dlodo Beach, Sine Beach, Klatak Beach, Popoh Beach, Sidem Beach, Gemah Beach, Nglarap Beach, Brumbun Beach, Molang Beach, Gerangan Beach, Bayem Beach, Coro Beach, Ombo Sawah Beach, Kedung Tumpang Beach, Kelinci Beach, Sanggar Beach, Sioro Beach, Ngalur Beach, Patok Gebang Beach, Banyu Mulok Beach, Pucang Sawit Beach, Pacar Beach, also Lumbung Beach. The populations in this study were Keboireng villager who involved in Klatak beach tourism process. This study selected participants who involved and had stayed long around the tourist attraction area of Klatak beach.

\section{Data Collection Methods}

This research used descriptive methods with quantitative and qualitative analysis techniques. The data used in this study are primary and secondary data. The Primary data was collected by interviewing, observing, and setting up focus group discussions (FGD) with tour managers and village and sub-district governments. Interviews were conducted with visitors, fishers, entrepreneurs around Klatak Beach, tourism managers. The secondary data obtained from government agencies, institutions, and the community.

\section{Data Analysis}

This research used SWOT analysis to analyze the aims to create the Blue Economy as policy alternatives. The results continued by the Analysis Hierarchy Process (AHP) to accomplish alternative policies on the Blue Economy that have been implemented by the Tulungagung Regency government. Based on research and coastal development plans, there are three groups of strategies which can be drawn to accomplish the Blue Economy, which is increasing fishery products, community empowerment, and optimizing fishing tourism management policies using the Blue Economy. Those strategy groups aim differently as 1) aims to improve fishery products so the resources can be better used and maximized, 2) aims to empower coastal communities so their abilities can develop further, 3) aims to increase the additional synergy values between the lobster farming business and other integrated tourism business on Klatak Beach so it could improve the community's economy and welfare. Klatak Beach located close to Gemah Beach and Bayem Beach, as on the following map.

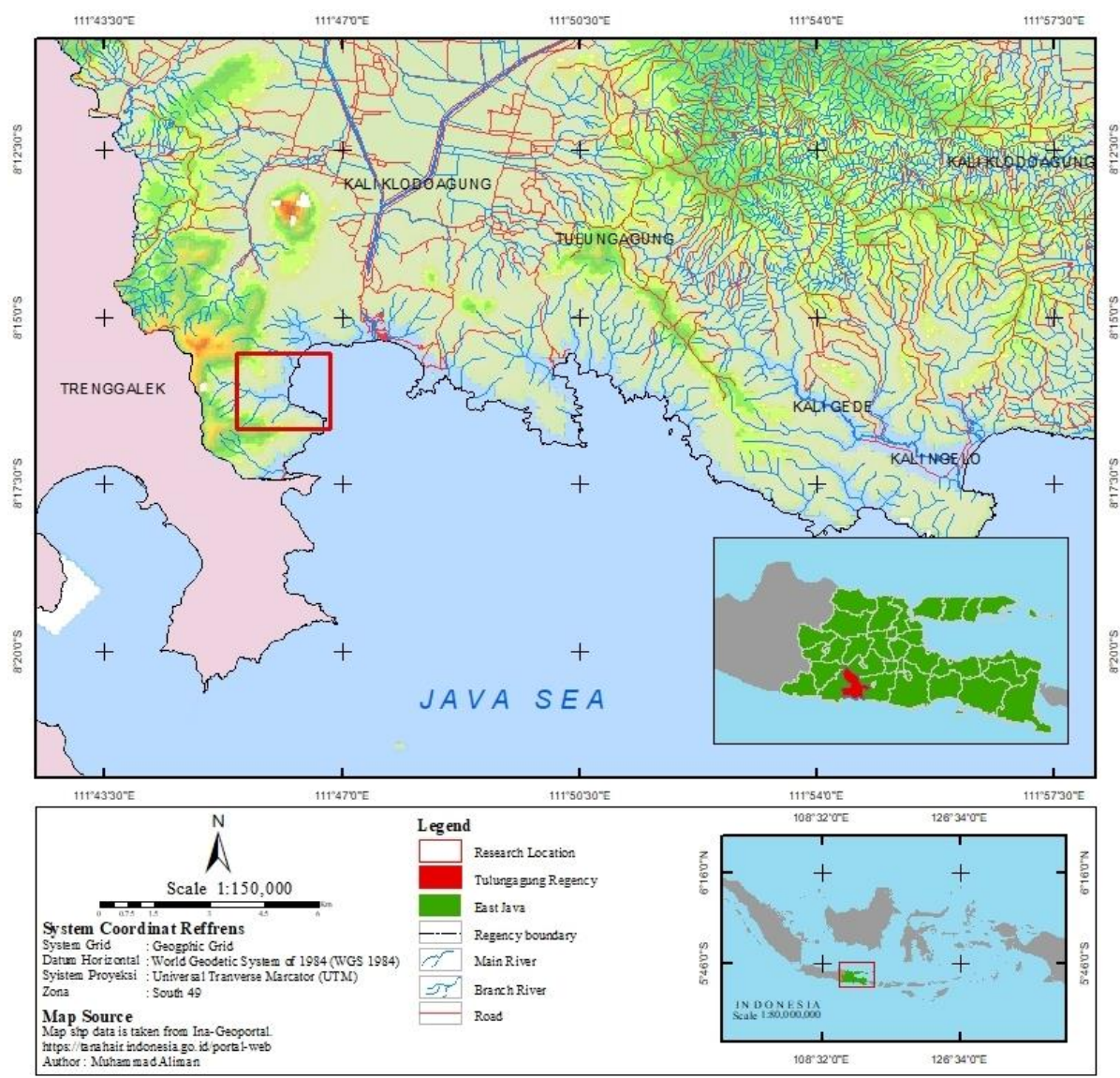

Figure 2. Map of Klatak Beach 
Before deciding the suggested policy, a SWOT analysis is conducted using the following formula:

Table 2. SWOT Matrix Source: Damanik dan Weber (2006)

\begin{tabular}{|c|c|c|}
\hline External Environment & Strengths & Weaknesses \\
\hline Opportunities & SO & WO \\
\hline Threats & ST & WT \\
\hline
\end{tabular}

Explanation:

a. SO: maximize strengths to reach opportunities

b. ST: maximize strengths to anticipate threats and try to create opportunities

c. WO: minimize weaknesses to reach opportunities

d. WT: minimize weaknesses to anticipate threats

\section{RESULTS AND DISCUSSIONS}

\section{The potential of fishing tourism in Klatak Beach}

Fishing tourism development in Klatak Beach also aims to improve community welfare while still trying to maintain the coastal environment. Klatak Beach is located in the Popoh bay. The location of the Klatak beach is in Klatak, Keboireng village, Besuki sub-district. Klatak Beach is located at longitude $111^{0} 46^{\prime} 11^{\prime}$ 'BT $-111^{0} 46^{\prime}$ ' 13 "East and at latitude $8^{0} 16^{\prime}$ 'LS - $8^{0} 16^{\prime}$ ' $12^{\prime}$ 'LS. Klatak Beach has located approximately $35 \mathrm{~km}$ from the city-center toward the south. The area of Klatak Beach is around 7,280 $\mathrm{m}^{2}$. According to the story of local fishermen, the "Klatak" comes from the sound of rock rubbing, moving and colliding. When the tide occurs with large waves is heard as the sound of "klatak-klatak". This beach is dominated by rock and black quartz sand. This beach has brown sand, but it is clean also the waves are calm. Besides the view of the big rock on Klatak Beach, there is also a collection of river rocks neatly arranged on the shoreline. Years ago, to get to the Klatak beach, people need to take a path and pass the wild forest or take an easier way by renting a boat started on the Popoh beach. Klatak Beach is located in Popoh Bay, near to Gemah Beach and Bayem Beach which was first developed. The distance of Klatak Beach from Tulungagung city-center is approximately 35 kilometres. Klatak Beach considered as a new beach to be open to the public, but there are already many visitors coming by. It is because this beach has its characteristics such as the beaches are still very beautiful and natural, has sparkling black sand, and there are many river stones scattered on the beach that show its beauty and have special attraction points for visitors. Klatak Beach is managed independently by Klatak community. Then the money from the taxes is used to improve the facilities and infrastructure of the tourist area such as improving road access, improving parking lots and expanding tourist areas (Papageorgiou, 2016).

The main characteristic of Klatak Beach compared to other beaches in Tulungagung is the existence of lobster farming, so that Klatak Beach is more developed as fishing tourism. Lobster (Palinuridae) is one type of aquatic biota that has important economic value. Statistical data on Indonesian fisheries in 2012 showed that lobster ranks as the fourth-highest export commodity after Penaeus shrimp. Compared to the number of lobster catches in the world, the caught is dominated by lobsters from the Nephropidae family (61\%), the Paniluridae family $(31 \%)$ and Scyllaridae (1\%) (Fahmi et al., 2018). Lobster is one of the aquatic commodities that have high economic value, produced by catching. To meet the high market demand for lobsters, especially in Asia, Europe and America, lobster farming has been provided in several countries, including Indonesia. Most lobster farming activities are breeding activities by capturing seeds from nature that is because there are no lobster seeds available from farming activities until now. Therefore, fishing tourism activities that integrated beach tourism with lobster farming also some interesting fishing location will encourage Klatak Beach as a new beach that attracted many visitors.

Klatak Beach is a beautiful tourist destination to visit. The communities around Klatak Beach Tourism area are also very welcoming for both local and foreign. Klatak Beach is one of the beaches that offer natural beauty. Trips to Klatak Beach present an exciting experience. The turns are quite tense with the rocks scattered along the way. However, the magnificent view at the end will relieve all tiredness throughout the trips. The uniqueness on Klatak Beach lies in the number of rocks arranged neatly along the shoreline. The rocks are clean and small, same rocks as usually found on the river. When hit by the waves, the rocks will produce the sound like 'Klatak' repeatedly. It is said from the local community that the name of Klatak Beach was taken from those sounds. Others large rocks, such as high cliff adding the beautiful view of the beach, along with clean brown sands and calm waves also increasing the elegant ambience on the beach. The mountains not far from the beach make the air on the beach feels cooler. There are facilities on the beach which include the parking area, rest area, public bathroom, food stalls, and many others. The following is one of the Klatak beach view locations as showed on figure 3 .
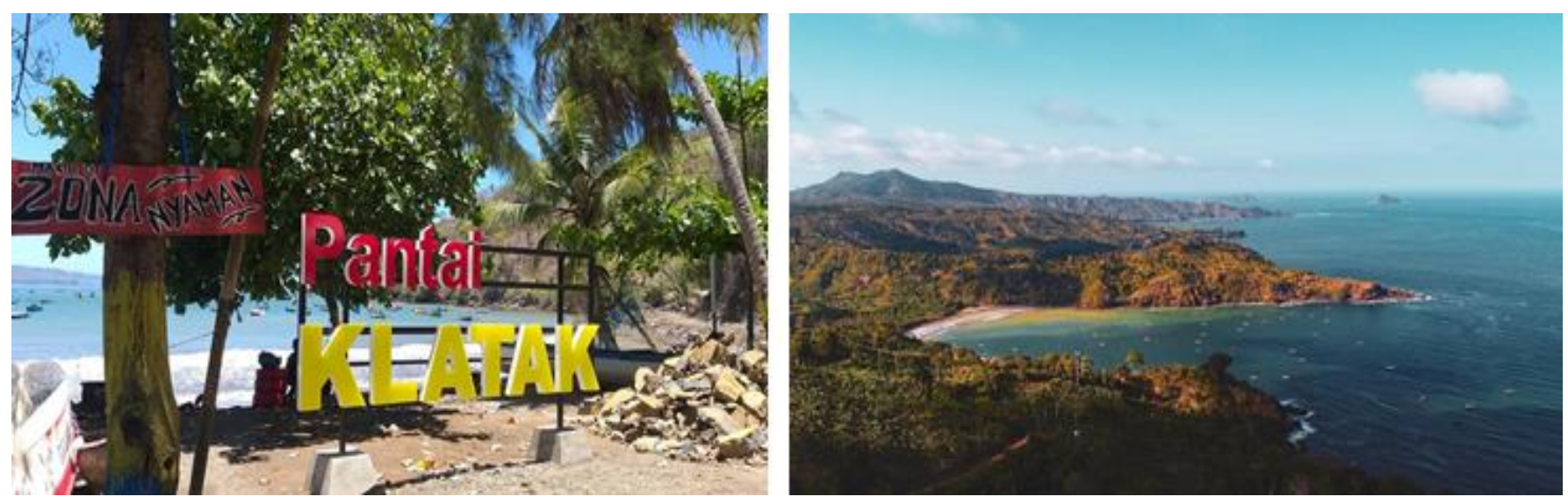

Figure 3. The view of Klatak Beach sign (left) and the view of Klatak Beach from above (right) (Source: Primary Data, 2019)

Klatak Beach has great potential to develop as fishing tourism. Community empowerment in Klatak Beach has been good through three groups of fishermen which is Mina Klatak, Rayap Pereng, and Pereng Mania. The policy made by the fishermen group and the government of Tulungagung Regency has supported to create the Blue Economy. These policies include (1) community empowerment with the 
supervision and control by marine resources, (2) development of economic groups of coastal communities, (3) development of infrastructure for lobster farming, (4) attractive fishing areas (5) tourism business services and community empowerment. (6) procurement of fishing aids. (7) training, developing fishery product and marketing. (8) development of tourism infrastructure. The following is a view of fishing boats on the Klatak beach as showed on figure 4. As fishing tourism area, Klatak Beach has a village where most of the people work as fishermen. The visitors can enjoy the local wisdom by local fishers who work to farm lobsters and crabs that are kept in cages. Although Klatak Beach was only developed and opened after the existence of the southern crossing lane (Jalan Lintas Selatan), the facilities and infrastructures in Klatak Beach such as toilets, prayer rooms, food stalls (selling seafood, especially lobsters and crabs), have developed well. For tourists who like fishing as a hobby can rent a fishing boat to find fishing spots accompanied and guided by the local fishermen.

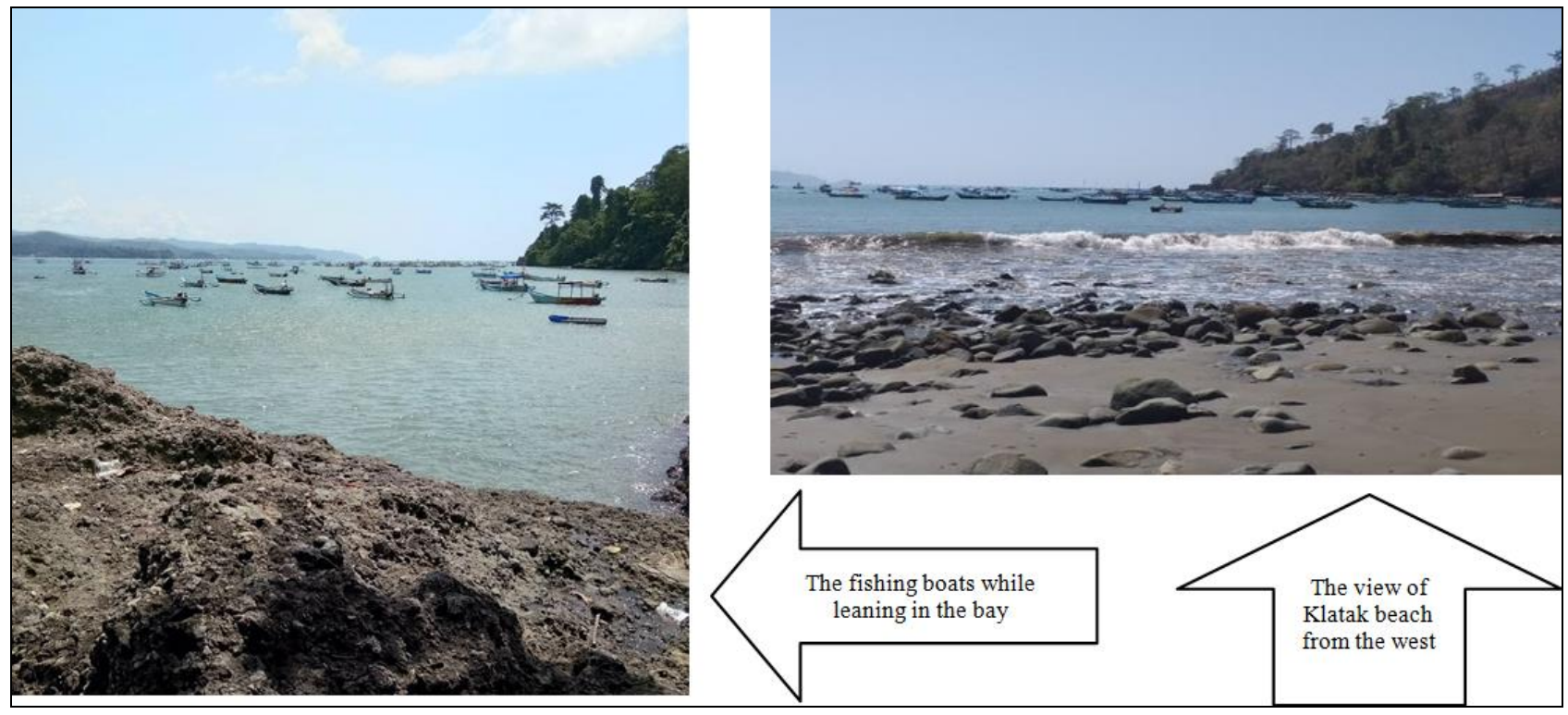

Figure 4. The View of Fishing Boats on Klatak Beach (Source: Primary Data, 2019)

\section{The Community Based Tourism in Klatak Beach}

Klatak Beach is one of the beaches that had potential aspects of developing as a tourism area. This statement is also supported by previous research (Astina et al., 2015), based on results of the analysis on phase II stated that the Bayem, Klatak, and Gerangan beaches are included in the category of the most priority coastal to be developed. Those three beaches have a score of 290, 275, and 260. A high score indicates that the beach has great potential to be developed as a tourist attraction. Whereas the second priority is Sidem be ach and the third priority is Brumbun, Nglarap, Sine, and Gemah beaches. The results of this study are also supported by Zain's research (2018) using GIS application which shows that of the three categories (low, medium and high) it is known that Klatak Beach is included in the medium potential tourism category with a total score of 58 to be developed.

The development of Tulungagung Regency's tourism began along with the opening of access through the south cross line (Jalur Lintas Selatan) to the southern region of East Java Province. With this infrastructure, Tulungagung Regency began to grow a new economy, such as the rise of beaches that are becoming widely known even though they have been around for a long time. Through the coastline of 54 kilometres with different characteristics, this made the Tulungagung government to prioritize to develop coastal tourism. The fishermen in the coastal area of Klatak can still catch fish while farming groupers, lobsters and crab fishes using floating net cages (Keramba Jaring Apung). In Klatak Beach itself, there are three groups of fishermen, namely Mina Klatak, Rayap Pereng, and Pereng Mania. Rayap Pereng is one of the fisher group that put catching and farming fish as the primary income. However, what Raya Pereng group has done is not easy. Government policies are needed to develop the small business of farming on groupers and lobster using floating net cages (Keramba Jaring Apung). Initially, the Raya Pereng group was formed by several Keboireng villagers who are often fishing around the Klatak beach.

The fishermen work daily by fishing, and some have other side businesses such as the seafood stalls around the coast. The fish usually caught are red snappers, barracudas, layur fishes, groupers, squids and lobsters. Besides, Klatak beach fishers also use lobsters as a side income, and some are farming it. Lobster farming by the Rayap Pereng fishermen was carried out in 2018. At first, the lobster seed was purchased by private funding, not group sources. In the beginning, the lobster that farmed came from the catch. Due to a ministerial regulation that prohibits to sale of lobsters unders 200 grams, then one of the leaders of the group started an initiative to farming lobsters that were not yet mature. The distribution has done domestically or abroad, and some were accommodated inside or outside of the village. The export quality is very selective, both in size and physical of the lobsters. The prices also vary, ranging from hundreds of thousands of Rupiah. An adult lobster with a minimum weight of 200 grams can sell for 200 to 250 thousand per fish. The pearl lobster sells up to 500,000 for each depending on its size, the heavier, of more expensive. In 2018 Klatak Beach was originally made to be a tourist area, especially fishing activities until later it was developed into a fishing tourism area. The fishing tourism using floating net cage is a tourism activity while enjoying the view of the floating net and seafood cuisine around the beach. This activity combines both fisheries and tourism activities. The development of floating net cages is carried out by Klatak fisher's community. The type of lobster farmed is pearl lobster. At present, farming using floating net cages has developed rapidly because the results are very promising to improve the economy of the community.

The wholesaler usually does not take lobsters from the fishers, but the fisher come to sell to the wholesaler by themselves. By the wholesaler, the products collected from the fishermen are sold to the lobster factory in Kediri then sent abroad. For medium-sized lobsters, it is usually sold by the fishermen directly to consumers. The lobster sold at tourist area or restaurants in the city is the product from those fishermen. Still, the lobster sales promotion has not used the mass media or online until now.

The floating net cages used for lobster farming consist of a framework, buoys, and cage net. The framework functions as a support to hang nets of $11 \times 11 \mathrm{~m}^{2}$ divided into nine plots of $3 \times 3 \mathrm{~m}$ and made of petung bamboo as many as 16 sticks. It is equipped with guardhouse as well as storage for materials and work tools placed on each plot. The Buoys are made of $200 \mathrm{~L}$ of Styrofoam drums of 16 pieces. 
The SWOT Analysis of Fishing Tourism Potential in Klatak Beach

The development of fishing tourism using the floating cage net in Klatak Beach needs to be analyzed to find out how significant its potential is. The analysis to determine this potential uses a SWOT analysis that can measure strengths, weaknesses, opportuni ties and threats of fishing tourism in Klatak Beach. Following are the results of the SWOT analysis in table 3.

Table 3. IFAS and EFAS matrix of Klatak Beach (Source: Analysis of Research Data, 2020)

\begin{tabular}{|c|c|c|c|}
\hline \multicolumn{4}{|l|}{ Internal Factor } \\
\hline Strengths & Quality & Rating & Score \\
\hline 1. The beach has a length of 748 meters and a width of 22.7 meters & 0.30 & 3 & 0.90 \\
\hline 2. The cleanliness is maintained well & 0.40 & 3 & 1.20 \\
\hline 3. The security is maintained conducive & 0.10 & 3 & 0.30 \\
\hline 4. Has interesting rock arrangements view & 0.40 & 3 & 1.20 \\
\hline 5. Has a beautiful fishing spot & 0.40 & 3 & 1.20 \\
\hline 6. The lobster farming support for economic improvement & 0.30 & 3 & 0.90 \\
\hline 7. The local fishing culture supports the Blue Economy & 0.30 & 4 & 1.20 \\
\hline 8. Have a Beach Manager & 0.20 & 3 & 0.60 \\
\hline \multicolumn{2}{|l|}{ Total } & & 7.50 \\
\hline Weaknesses & Quality & Rating & Score \\
\hline 1. The roads access are rather difficult & 0.40 & 5 & 2.00 \\
\hline 2. The tourism infrastructure is still limited & 0.30 & 4 & 1.20 \\
\hline 3. The promotion was not done by the Department of Tourism & 0.20 & 4 & 0.80 \\
\hline 4. The tourism management has not been maximized & 0.40 & 5 & 2.00 \\
\hline 5. The communication networks that have not been maximized & 0.50 & 3 & 1.50 \\
\hline \multicolumn{2}{|l|}{ Total } & & 7.30 \\
\hline
\end{tabular}

$\mathrm{X}=$ Strengths - Weaknesses $=\mathbf{0 , 2 0}$

\begin{tabular}{|c|c|c|c|}
\hline \multicolumn{4}{|l|}{ External Factor } \\
\hline Opportunities & Quality & Rating & Score \\
\hline 1. The rhythmic sound of rocks from the waves & 0,40 & 5 & 2,00 \\
\hline 2. Has some regulations that manage the development of coastal tourism & 0,40 & 3 & 1,20 \\
\hline 3. Uses as special tourism area for rock heat therapy & 0,20 & 4 & 0,80 \\
\hline 4. Get support from the local community & 0,50 & 3 & 1,50 \\
\hline 5. Has many visitors coming & 0,50 & 3 & 1,50 \\
\hline 6. Has a national fishing competition event & 0,30 & 3 & 0,90 \\
\hline \multicolumn{2}{|l|}{ Total } & & $\mathbf{7 , 7 0}$ \\
\hline Threats & Quality & Rating & Score \\
\hline 1. There are no investors yet & 0.40 & 5 & 2.00 \\
\hline 2. The garbage from the Niama river during the rainy season & 0.40 & 3 & 1.20 \\
\hline 3. Some people taking the rock for build habitation & 0.20 & 4 & 0.80 \\
\hline 4. Better attraction from other beaches & 0.50 & 3 & 1.50 \\
\hline \multicolumn{2}{|l|}{ Total } & & 7.30 \\
\hline
\end{tabular}

Y = Opportunities - Threats $=\mathbf{0 , 4 0}$

The results of the IFAS and EFAS matrix ratings are weighted as in table 3. The quadrant position of the Klatak Beach tourism marks of $\mathrm{x}$ and $\mathrm{y}$ values. The value of $\mathrm{x}$ is 0.20 obtained from the internal factors as the result of strength (S) reduced by weakness (W). The value of $y$ is 0.40 obtained from the external factors as the result of opportunity $(\mathrm{O})$ reduced by threat $(\mathrm{T})$. Therefore, the quadrant place on Quadrant I based on the $\mathrm{x}$ and y value $(0.20,0.40)$. The position means that Klatak Beach tourism is in a developing condition, where its place on the Stable Growth Strategy position. Stable Growth Strategy is the stable growth development that carried out in stages, and the target is adjusted to the conditions. SO (Strengths-Opportunities) strategy or called White Area on Klatak Beach means that this beach has prospective opportunities also has the potential to take advantage of developing the existing potential. The following is a SWOT analysis in the Klatak beach as showed on Figure 5.

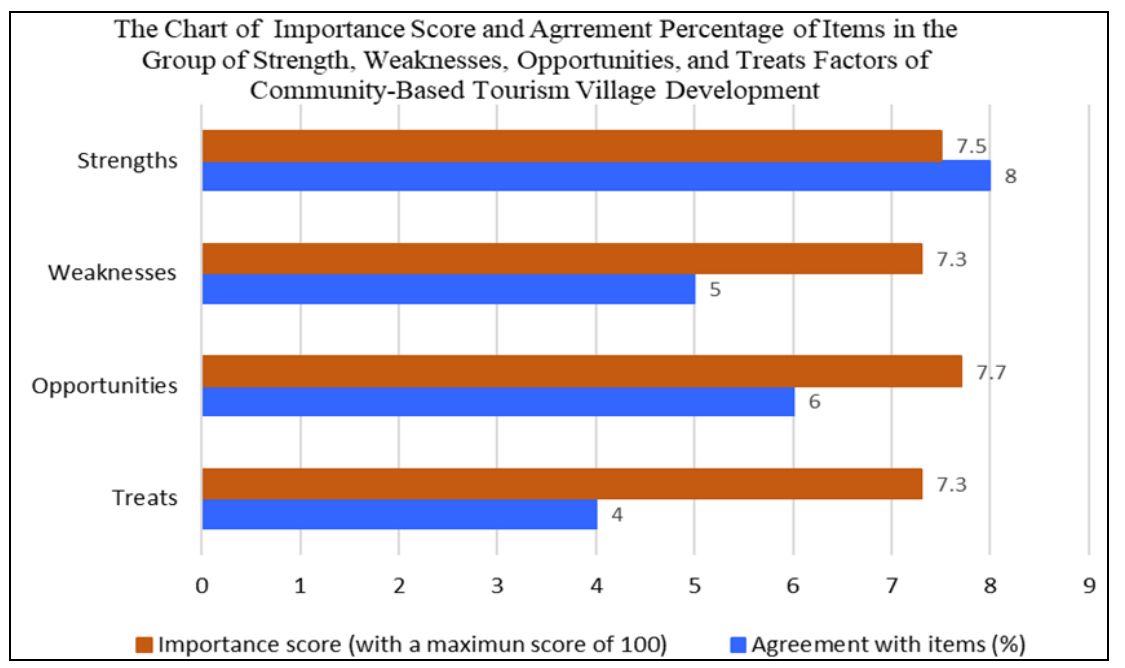

Figure 5. The SWOT Analysis of Klatak Beach in Tulungagung (Source: Analysis of Research Data, 2020) 
Based on table 3, the results of the SWOT analysis described in quadrant form, as showed in the following figure.

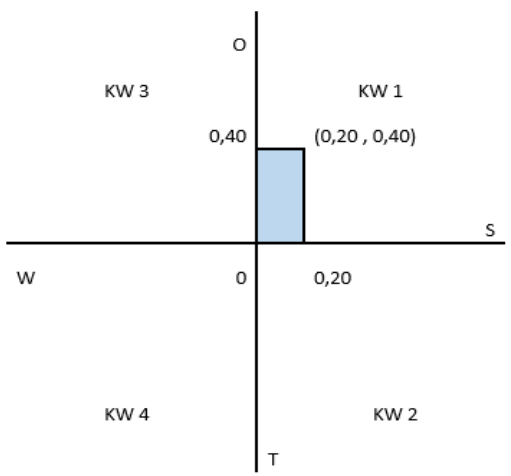

Figure 6. Quadrant Position of Klatak Beach Tourism (Source: Analysis of Research Data, 2020)

Based on the quadrant position in figure 6, Klatak Beach places on quadrant I or SO (Strengths-Opportunities). The SO (StrengthsOpportunities) strategy or called White Area means that this beach not only has prospective opportunities but also has the potential to maximize the opportunities to develop the existing potential. The strategy must be applied in this condition is to support an aggressive growth policy (growth-oriented strategy). Based on these conditions, Klatak Beach must form a strategy related to tourism activities to develop the blue economy. The policy based on S-O includes improving road accesses, adding tourist facilities, and improving infrastructure. The W-O policy includes improving communication networks that have not been maximized and improving tourism management. The policy based on S-T includes reducing the activities of taking rocks for building materials and minimizing the competitiveness from other beaches. Lastly, the policies based on W-T include adding more activities to increase promotion and inviting more investors.

Concrete step in the developing strategies based on results of the SWOT analysis includes:

1. Strengthening the concept of fishing tourism in Klatak Beach.

2. Improving the local economic development, so that the local government and the community can collaborate and become the stakeholders with a full interest to develop their village. The way is to develop an economic unit owned the community called BUMDES (Badan Usaha Milik Desa) and also a cooperative shop to support the Klatak Beach tourism activities.

3. Encouraging linkage with travel units (travel agents) to promote the Klatak Beach tour.

4. Encouraging the community to carry out intense promotions and associating programs with travel agents through the website.

5. Encouraging participation and community empowerment around Klatak Beach, especially fisher communities.

6. Encouraging strategic business units to support coastal development business in need such as add more lodging places, expanse the parking lots, improve souvenir businesses, add more convenience stores, public bathroom, restaurants and crossover services with fishing boats.

The results also indicated that financial investments are essential for Community-Based Tourism. Financial investments are not an end, as marketing planning and skills development can ensure the success of Community-Based Tourism. This article explained that developing destinations will become success factors for Community-Based Tourism projects that used to create a tourism supply chain for residents and citizens of a tourism destination. To develop Community-Based Tourism, the role of the marketing planner must function properly. The people who involve in promotional activities must be familiar with the factors to make Klatak Beach as an attractive tourism area. The uniqueness must be explored as promotional material. This is also supported by the results of Strydom's research (2019), Khodir (2018); Giampiccoli (2020); Mearns (2015); Prabhakaran (2014). Environmental, economic and cultural sustainabilities in the development of this fishing tourism area are essential. Klatak Beach is famous for its beautiful view and clean environment. It is necessary to a void factors that cause a decrease in the quality of tourism so that promotion has been carried out intensively, and the development of infrastructure can provide benefits for the Klatak beach. Research on sustainable tourism is also supported by the results of research Mc Intyre (1993), Inskeep (1998), Matarrita (2010). The development of fishing tourism in Klatak Beach is expected to have a significant influence to the economy of the local community, especially for three groups of fishermen which are Mina Klatak, Rayap Pereng, and Pereng Mania. It is because those groups have initiated many activities for the development of Klatak Beach. However, with the entrance of investors from outsi de the Klatak area, it is hoped that it will not interfere the development of the local community, as supported by a previous study by Walpole et al (2000).

Lobsters and crabs farming in Klatak Beach, which began in 2018, is indeed needed to be developed. For development, there is still much assistance to do. As the results of Simon's research (2012) that increasing the empowerment of Fisheries and Aquaculture fish needs to be mentoring in its farming, including assistance in processing and marketing as explained by the Indonesian Maritime Council (2012) and Bappenas (2016). The Tulungagung region is a karst area, so not all places can be used as the agricultural field. Therefore, alternative agriculture that needs to be encouraged is by fish farming activities. From farming lobster and crab, in the future it can be developed into more diverse activities but still in the main plan, which is the development of fishing tourism that has environmental, economic, and cultural sustainability by applying the Blue Economy concept, and this is also supported by research from Tegar et al (2018).

\section{CONCLUSION}

The results showed that Klatak Beach was included as a potential to develop as the tourism area. The Fishing tourism activities have been able to empower the community on the beach Klatak through three groups of fishermen which are Mina Klatak, Rayap Pereng, and Pereng Mania. The policy made by the fishermen group and the government of Tulungagung Regency has supported to create the Blue Economy. The fishing tourism activities that refer to Blue Economy need to focus on environmental, economic, and the cultural sustainability of the surrounding community. This study recommends that tourism managers and local governments should make lobster fishing tourism as a model of developing tourism based on the Blue economy. Further research can be continued on fishing tourism types with different morphological characteristics.

\section{Aknowlegments}

Thank you to the Klatak coastal community, especially fishers, tour managers and visitors. Also, to the head of Keboireng Village and the chief of Besuki Sub-District of Tulungagung Regency. This research has no conflict of interest or any intention towards individuals or groups. 


\section{REFERENCES}

Arintoko, A., Ahmad, A.A., Gunawan, D.S. \& Supadi, S. (2020). Community-based Tourism Village Development Strategies: A Case of Borobudur Tourism Village Area, Indonesia. Geojournal of Tourism and Geosites, 29(2), 398-413. https://doi.org/10.30892/gtg.29202-477

Astina, I Komang., Yusuf S. \& Purwanto. (2015). The Potential and Development of Tourism Beach in Tulungagung Regency Using Spatial Analysis, SWOT and GIS. Jurnal Pendidikan Geografi, 20, 1.

Apriliani, K.F. (2014). Analisis Potensi Lokal di Wilayah Pesisir Kabupaten Kendal dalam Upaya Mewujudkan Blue Economy [Analysis of Local Potential in the Coastal Area of Kendal Regency to Create a Blue Economy]. Economics Development Analysis Journal. vol 3 , no 1.

Bappenas. (2016). Tourism Development Plan. Based on Multilateral Meeting 1, 2016 February 29. Jakarta: Division of Economy-Ministry.

Bari, A., \& C Eng, Fieb, Frina. (2016). Our Oceans and the Blue Economy: Opportunities and Challenges. 10th International Conference on Marine Technology, MARTEC 2016. Procedia Engineering, 194 (2017). 5 - 11.

Bengen, D. (2010). Maritime State Development Perspective. Indonesia Maritim Institute, Jakarta.

Budiawati, A. (2013). Program Kementerian ini Angkat Ekonomi Pulau Kecil. http://bisnis.news.viva.co.id/news/read/446991-program-kementerian-iniangkat-ekonomi-pulau-kecil

Dahuri, R. (2001). Integrated Management of Coastal and Ocean Areas. PT Pranadya Paramita. Jakarta.

Damanik, J., dan Helmut, F., \& Weber. (2006). Perencanaan Ekowisata: Dari Teori ke Aplikasi [Ecotourism Planning: From Theory to Application]. PUSPAR UGM dan Penerbit Andi. Yogyakarta.

Dermawan, A., \& Aziz, A.M. (2012). Development of Small Islands Tourism to Support the Implementation of Blue Economy, The 8th National Conference on Coastal, Marine and Small Islands Management, Mataram.

Fahmi, V., Pratama I.S., \& Ridwanudin, A. (2018). The Growth of Panulirus Homarus Lobster with Moisture Feed. Oseanologi dan Limnologi di Indonesia, 3, 2, 95-103. https://doi.org/10.14203/oldi.2018.v3i2.165

Fandeli, C. (1997). Dasar-dasar Manajemen Kepariwisataan Alam [Fundamentals of Nature Tourism Management], Yogyakarta: Liberti.

Firdaus, F., Shalihin, N., Anggreta, D.K., Yasin, F., \& Tutri, R. (2019). Improving the Benefits of Karamba Into Tourism Activities: An Effort to Reduce the Ecological Impact of Aquaculture in Maninjau Lake, Indonesia. GeoJournal of Tourism and Geosites, 26(3), 726-736. https://doi.org/10.30892/gtg.26304-392

Giampiccoli, A., Abdul Muhsin, B. \& Mtapuri, O. (2020). Community-Based Tourism in The Case of The Maldives. GeoJournal of Tourism and Geosites, 29 (2), 428-439. https://doi.org/10.30892/gtg.29204-479

Hakim, M.F. (2013). Blue Economy of Coastal and Marine Fisheries. Department of Development Economics, Faculty of Economics, Semarang State University, Indonesia. Economics Development Analysis Journal. http://journal.unnes.ac.id/sju/index.php/edaj

Haris, A. (2012). The Design of Fishing Tourism based on Conservation in Small Marine Islands: The Case of Dulla Island, Tual City, Maluku Province, Disertasi, Institut Pertanian Bogor, Bogor.

Inskeep, E \& World Tourism Organization. (1998). Guide for Local Authorities on Developing Sustainable Tourism. World Tourism Organization.

Kazimoto, P. (2013). The Effect of Village Development Strategies on Community Socio-Economic Development in Tanzania, Arumeru District. International Journal of Research in Social Sciences, 2(3), 33-39.

Kodir, A. (2018). Tourism and Development: Land Acquisition, Achievement of Investment and Cultural Change (Case Study Tourism Industry Development in Batu City, Indonesia), GeoJournal of Tourism and Geosites, vol. 21, no. 1, pp. 253-265. https://doi.org/10.30892/gtg.21120-285

Kodir, A., Tanjung, A., Sumarmi, Ahmad, R., \& Simanjuntak, T.B. (2019). Tourism Governance in Komodo National Park, Indonesia: Blessing or Curse? GeoJournal of Toursm and Geosites, 27(4), 1401-1417. https://doi.org/10.30892/gtg.27424-443

Kurniawati, E., Sumarmi, S., \& Aliman, M. (2020). Participation of Green Environmental Group and Ulur-ulur Local Wisdom on Buret Lake Ecotourism Management in Karst Area of Tulungagung, Indonesia. GeoJournal of Tourism and Geosites, 30 (2 supplement), 889-895. https://doi.org/10.30892/gtg.302spl15-519

Mitchell, L.S., \& P.E. Murphy. (1991). Geography and Tourism, Ann. Tour. Res., vol. 18, no. 1, pp. 57-70.

Matarrita-Cascantea, D., Brennanb, M.A. \& Luloff, A. E. (2010). Community Agency and Sustainable Tourism Development: the case of La Fortuna, Costa Rica. Journal of sustainable tourism, 18, 6, p. 9.

McKinley, E., Aller-Rojas, O., \& Hattam, C. (2019). Charting the Course for a Blue Economy in Peru: a research agenda. Environ Dev Sustain. 21, 22532275. https://doi.org/10.1007/s10668-018-0133-z

McIntyre, G. (1993). Sustainable Tourism Development: Guide for Local Planners, Sustain. Tour. Dev. Guid. local planners.

Mearns, K.F., \& Lukhele, S.E. (2015). Addressing the Operational Challenges of Community-Based Tourism in Swaziland. African Journal of Hospitality, Tourism and Leisure, no. 1, vol. 4, p. 1-13.

Munir Z.M. \& Taufik M. (2018). The development of Natural Tourism Potential of Tulungagung Regency with Geographic Information Systems. Program Studi Teknik Geomatika ITS

Nurwenda, E. (2013). The Effect of Fishing Tourism on Fishers Household Income in Santolo Beach, Garut Regency, Skripsi, Universitas Padjadjaran.

Papageorgiou, M. (2016). Coastal and Marine Tourism: A Challenging Factor in Marine Spatial Planning. Ocean \& Coastal Management, 129, 44-48. https://doi.org/10.1016/j.ocecoaman

Prabhakaran, S., Nair, V. \& Ramachandran, S. (2014). Community Participation in Rural Tourism: Towards a conceptual framework, Procedia - Social and Behavioral Sciences, 144, 290 - 295.

Priyono. A. (2014). Delivered at the Indonesian Maritime Congress on 23-24 December 2014. Yogyakarta, Ministry of Tourism and Creative Economy of the Republic of Indonesia. https://docplayer.info/30161634-Strategi-pengembangan-industri-pariwisata-bahari.html

Rekdale, P. (2013). Blue Economy Indonesia. Jakarta: Blue Economy Indonesia.

Saaty, T.L. (1993). Decision Making for Leaders, Analytic Hierarchy Process for Decision Making in Complex Situations. Pustaka Binama Pressindo. Jakarta.

Satria, D. (2009). Local Economic Based Ecotourism Development Strategies to Reduce Poverty in Malang Regency. Journal of Indonesian Applied Economics. 3, 1, 37-47. http://dx.doi.org/10.21776/ub.jiae.2009.003.01.5

Simon F.S., Mathew B, \& Weimin M. (2012). Regional Overview of Fisheries and Aquaculture in Asia and the Asia Pacific. Asia Pacific Fishery Commission, FAO, UN.

Strydom, A.J., Mangope, D., \& Henama, U.S. (2019). Making Community-Based Tourism Sustainable: Evidence from The Free State Province, South Africa. GeoJournal of Tourism and Geosites, 24(1), 7-18. https://doi.org/10.30892/gtg.24101-338

Tegar R, Dimas; R.O. \& Saut Gurning. (2018). Development of Marine and Coastal Tourism Based on Blue Economy. International Journal of Marine Engineering Innovation and Research, 2(2). 128-132 https://doi.org/10.12962/j25481479.v2i2.3650

Undang Undang Nomor 1 Tahun (2014). About the Management of Coastal Areas and Small Islands. https://www.jogloabang.com/pustaka/uu-1-2014perubahan-uu-27-2007-pengelolaan-w3pk

Walpole, J.M. \& Goodwin, J.H. (2000). Local Economic Impacts of Dragon Tourism in Indonesia, Annals of Tourism Research, 27, 3, 559-576. http://10.0.3.248/S0160-7383(99)00088-2

*** Indonesian Maritime Council. (2012). Marine Economic Policy with the Blue Economic Model. Jakarta: Dewan Kelautan Indonesia

*** International Trade Center. (2020). Trade Map_List of exporters for the selected product (Fish and crustaceans, molluscs and other aquatic invertebrates). Https://www.trademap.org/. https://www.trademap.org/tradestat/Country_SelProduct_TS.aspx?nvpm

*** Law No. 31 of 2004 on Fisheries. http://www.dpr.go.id/dokjdih/document/uu/32.pdf

*** Law No. 10 of 2009 on Tourism. http://www.kemenparekraf.go.id/post/undang-undang-republik-indonesia-nomor-10-tahun-2009 